\title{
The Lupo Legacy: Agents for Change
}

\author{
B. Glenn Chandler*
}

\begin{abstract}
The story of the Lupo family musicians is an amazing story of survival and accomplishment. Having escaped the Spanish Inquisition of 1492, their family settled in northern Italy, which by late fifteenth century had become an important center for musical innovation. There, the three Lupo brothers emerged as professional string players around the time the violin was invented in the same region. After a few years in Venice they emigrated to England in 1540 to play at the court of Henry VIII. For the next 102 years Lupo family musicians performed at the royal court in a country where it was illegal for Jew to live. The Lupo musicians were integrally involved in the development of instrumental music as the renaissance style gave way to the exciting new baroque style. Concurrently, important social changes were taking place in England as well, raising the question: "What role did the Lupo family play in the musical and social changes during this time?"
\end{abstract}

\section{Introduction}

In 1539 King Henry VIII (1491-1548) charged his chief minister, Thomas Cromwell (1485-1540), with the task of improving the quality of music in the royal court shortly before he was to marry Anne of Cleves. ${ }^{1}$ Cromwell worked through an agent in Venice to recruit the finest musicians available. The agent first recruited five brothers from the Bassano family, considered among the finest wind instrument players in Venice. Within a month he also recruited six viol players, among which were Ambrose, Alexandro and Romano of Milan, Alberto and Vincenzo of Venice, and Juan Maria of Cremona, all of whom arrived in London by the first of November $1540 .{ }^{2}$

Ambrose, Alexandro and Romano of Milan are believed to have been brothers descended from Sephardic Jews who left the Iberian Peninsula around the time of the Spanish Inquisition of $1492 .^{3}$ The most astonishing element regarding the recruitment of Jewish musicians to England in the sixteenth century is that it was illegal at the time for Jews to live in England. And although several efforts were made in the sixteenth and seventeenth centuries to change English law, they were unsuccessful. It was not until the mid-nineteenth century that the laws were finally changed allowing Jews to live legally in England. ${ }^{4}$

*Professor, University of Texas at Austin, USA.

1. Peter Holman, Four and Twenty Fiddlers: The Violin at the English Court 1540-1690 (Oxford: University Press, 1993; reprinted by Clarendon Press, 1995), 78-80.

2. Letters and Papers, Foreign and Domestic, of the Reign of Henry VIII, Vol. XVI, arrang. and catal. James Gairdner and R. H. Brodie (London: Eyre \& Spottiswoode, 1898).

3. Holman, Four and Twenty Fiddlers, 82.

4. Hywel Williams, Cassell's Chronology of World History (London: Weidenfeld \& Nicolson, 2005), 316. 
Amazingly there would be members of the Lupo family in the service of the English monarchy from 1540 until the English Civil War of 1642 when there was no monarchy and the court music ensembles were disbanded. This was an important time in the development of instrumental music in Europe. The violin was invented in the early sixteenth century and would eventually replace the viola da gamba as the primary stringed instrument at the court. The Lupos are thought to have brought with them to England both viols and violins, thus, making them among the earliest musicians to adapt to the violin family of instruments. ${ }^{5}$ Two of Ambrose's sons were also musicians and followed in his footsteps playing viol and violin at the royal court, as did three grandsons and one great-grandson. Several Lupo family musicians were composers as well as performers and left a significant body of string compositions, many of which are still performed today. ${ }^{6}$

This scenario raises a number of interesting questions. Why would these Jewish musicians be recruited to a country where it was illegal for Jews to live? And why would they consider moving there under these conditions and risk imprisonment? How were they able to survive under these circumstances, much less thrive? What role, if any, might they have played in changing the social conditions that eventually led to a change in the law? And what role, if any, did they play in the musical developments of the sixteenth and seventeenth centuries? It is the purpose of this paper to explore these and related questions in order to comprehend and appreciate the significance of the Lupo family's long and unlikely journey and the incredible legacy they left behind.

\section{Origin of the Lupo Family}

It is not clear when the ancestors of the three brothers actually arrived in Italy, but likely it was shortly after the Spanish Inquisition of 1492. Ambrose was born in Milan around 1505 and is known to have lived in Venice at least five years before going to London in $1540 .{ }^{7} \mathrm{He}$ was the first of his family to adopt the surname Lupo, which means wolf in Italian. It was a favorite name adopted by many Jews when surnames began to be adopted, and was likely inspired by a biblical reference: Benjamin is a ravenous wolf; in the morning he devours the prey; in the evening he divides the plunder. ${ }^{8}$

5. Holman, Four and Twenty Fiddlers, 87.

6. Ibid., 31.

7. A Biographical Dictionary of English Court Musicians, 1484-1741, comp. Andrew Ashvee and David Lasacki, assist. Peter Holman and Fiona Kisby, vol. II (Aldershot: Ashgate, 1998), 745-746.

8. Bible, New International Version (NIV) (Grand Rapids: Zondervan Press, 2011), Genesis 49: 27. 
According to an augmentation of his coat of arms granted towards the end of his life, Ambrose was listed as ... son of Baptist from Castello maiori and Busto in Normandy, in the republic of Malan..$^{9}$ It is assumed that Baptist settled in what is now Busto Arsizio, some 40 kilometers northwest of Milan, and later moved his family to Castello, a major section of Venice located immediately behind the Basilica of San Marco. And, although Busto Arsizio is not in Normandy, the confusion is understandable since the French occupied Milan several times during the early sixteenth century. ${ }^{10}$

No proof has been found that Alexandro, Ambrose and Romano were actually brothers, but the circumstantial evidence strongly suggests it. For instance, a lay subsidy assessment in England in 1542 reads: ... in St Gabriel's Fenchurch Street John Baptist and Alexander ... in t[he]house of Violet str[anger] in goodes' $£ 11$ 11s. ${ }^{11}$ Considering that John Baptist was living with Alexandro in London; that Baptist was cited as the father of Ambrose in the augmentation of his coat of arms; that Ambrose, Alexandro and Romano were born in Milan; and that all three were hired together by Henry VIII in 1540; the circumstantial evidence appears sufficient to assume they were brothers.

If there were any doubts about their Jewishness, an incident occurring a little over a year after their arrival in London should dispel them. On 29 January 1541/2 Henry VIII ordered the New Christians (term associated with converted Jews in England) thrown into prison. Although Henry had actually encouraged Jews to settle in England, it was still illegal, and on occasion there were waves of anti-Semitism; so to appease those complaining Henry had the New Christians imprisoned.12 While in prison John Anthony, one of the court sackbut players, died and Ambrose witnessed his will. Interestingly, the probate record lists the dead man as Anthonii Moyses and Ambrose as Ambrosius deolmaleyex. In the Jewish tradition Anthonii Moyses means Anthony son of Moses, and deolmaleyex is thought to be a clerk's misinterpretation of de Olmaliach, or de Almaliach, a form of the Sephardic name Elmaleh..$^{13}$ It is not clear why Ambrose decided at that moment to reveal his Jewishness. Maybe he felt it was by then common knowledge, or that he thought he had nothing to lose. Or, perhaps he felt an obligation to honor his dead friend in a significant manner regardless of the outcome. Whatever the reason it seemed not to matter, for the musicians were quietly slipped out of the country until the

9. Grantees of Arms Named in Docquets and Patents to the End of the Seventeenth Century, ed. Harry Rylands (London: Harleian Society Publications, 1915), 160.

10. Holman, Four and Twenty Fiddlers, 81.

11. A Biographical Dictionary of English Court Musicians, vol. II, 744-745.

12. Holman, Four and Twenty Fiddlers, 86.

13 Roger Prior, "Jewish Musicians at the Tudor Court," Musical Quarterly 69 (1983), 257-258. 
incident blew over and then reappointed to the king's consort on 23 February 1543/4, backdated to 1 November $1543 .{ }^{14}$

Very little is known about Baptist and his family before they came to Italy or from where on the Iberian Peninsula they came, although there was a dispatch dated 29 January 1541/2 by the Imperial ambassador, Eustace Chapuy, that said: Henry VIII had lately ordered the arrest and imprisonment of the new Christians who came from Portugal. ${ }^{15}$ This reference to Portugal could have been based on fact or on conjecture, and unfortunately no other information about their origin has been found. However, since the expulsion of Jews from Portugal was not until 1536, the timing of Baptist's move suggests they came from Spain. ${ }^{16}$ As such, understanding the history and conditions of Jewish life in Spain leading up to the 1492 Expulsion of Jews ${ }^{17}$ is essential to understanding the Lupo legacy.

\section{Jewish Life on the Iberian Peninsula Prior to 1492}

Jews had lived on the Iberian Peninsula since the time of the Greeks, arriving shortly after the destruction of the first Temple in 586 BCE (423 BCE in Jewish chronology). ${ }^{18}$ A sixteenth-century scholar, Gedaliah ibn Jechia, claims when King Ferdinand and Queen Isabella commanded all Jews to leave Spain in 1492 the Jews of Toledo sought exception, claiming their families were already in Toledo when Christ was crucified and, therefore, they should not be blamed for his death. Their claims, however, fell on deaf years and they were forced to leave Spain like the rest of the Jews. ${ }^{19}$

After the Romans took control of the Peninsula following the Second Punic War of 218-202 BCE, they sent as many as 90,000 enslaved Jews to the Peninsula. ${ }^{20}$ By the third century Jewish citizens were well established in Hispania, as it was then called, and were involved in the civic and social life of their communities. Then, in the early fourth century the Church issued several

14. A Biographical Dictionary of English Court Musicians, vol. II, 746.

15. Prior, Jewish Musicians at the Tudor Court, 260.

16. António José Saraiva, "Introduction to the English edition," in The Marrano Factory: The Portuguese Inquisition and its New Christians, trans. H. P. Solomon (Leiden: Brill Publishers, 2001), 9.

17. Documentos acerca de la expulsion de los Judios (Documents about the expulsion of Jews), No. 177, ed. Luis Suarez-Fernandez (Valladolid: C.S.I.C., 1964), 391-395.

18. Moses ben Machir, Seder Ha-Yom (Venice: Gara, 1604), 15.

19. Gedaliah ibn Yahya ben Joseph, Shalshelet Ha-Kabbalah (Venice, 1587; reprinted Brookfield, MI: Targum Press, 2004), 271.

20. Heinrich Graetz, History of the Jews, vol. III (Philadelphia: The Jewish Publication Society of America, 1894), 42. 
Canons designed to create separation between Christians and Jews. These were among the earliest acts of anti-Semitism. ${ }^{21}$

When the Visigoths conquered Hispania in the early sixth century, the Jews were initially allowed to live in relative peace because the Visigoths had little interest in religious practices. That changed, however, when King Recared converted to Catholicism in 587.22 At the Council of Toledo in 589 it was determined that children of mixed marriages between Jews and Gentiles would be baptized. When King Sisebut assumed the throne in 610 he rigorously enforced this edict, leading a campaign to force all Jews to be baptized or expelled..$^{23}$

Two developments brought some hope to the persecuted Jews in the late seventh century. First, the Moors, who had been making their way across Europe, established a foothold in the southern part of Spain, and the Jews, viewing them as liberators, greeted them eagerly. At about the same time the Holy Roman Empire sent its navy to the area in an attempt to insight uprisings among the Jews against the Visigoths. They had no intention of helping the Jews; their goal was to stop the Moorish advances in Spain. So, in 695 when the Jews welcomed the outsiders the Visigoths charged them with plotting against the authorities and condemned them to slavery. ${ }^{24}$

In 711 the Moors defeated the Visigoths at the battle of Tyriq ibn Ziyad, marking the beginning of Moorish rule in Hispania. Their rule would continue in varying parts of the Peninsula until 1492, the height of which was between the eighth and twelfth centuries. ${ }^{25}$ Generally speaking, the Jews fared better under Moorish rule than under Christian rule, especially after Abd-arRahman I established Umayad rule in 755 . This was a secular government that allowed Jews, Christians and other minorities to practice their own religions. At that time Muslims controlled almost a third of the known world's population and, with much of their kingdom non-Muslim, the government understood the importance of involving leaders of the other religions in their governance. ${ }^{26}$

21. Samuel Laeuchli, Power and Sexuality: The Emergence of Canon Law at the Synod of Elvira (Philadelphia: Temple University Press, 1972), 75-76.

22. Solomon Katz, "Monographs of the Mediaeval Academy of America," in No. 12, The Jews in the Visigothic and Frankish Kingdoms of Spain and Gaul (Cambridge: The Mediaeval Society of America, 1937), 10.

23. Yom Tov Assis, The News of Spain: From Settlement to Expulsion (Jerusalem: The Hebrew University of Jerusalem, 1988), 10.

24. Norman Stillman, "Aspects of Jewish Life in Islamic Spain," in Aspects of Jewish Culture in the Middle Ages, ed. Paul E. Szarmach (Albany: State University of New York Press, 1979), 53.

25. Reinhardt Dozy, Spanish Islam: A History of the Muslims in Spain, trans. Francis G. Stokes (London: Chatto \& Windus, 1913), 133.

26. H. U. Rajman, A Chronology of Islanic History 570-1000, 3rd edition (London: Ta-Ha Publishers, Ltd, 1999), 128. 
With the freedom to practice their religion openly, Jews from other parts of the world made their way to Hispania. ${ }^{27}$ Under the reign of Abd-ar-Rahman III (882-955), the first Caliph of Córdoba, the real golden age of Jewish life was ushered in. Jewish councilor Hasdai ibn Shaprut was appointed supervisor of foreign trade, and as such he was able to communicate with Jews throughout the world. It was at this time that the concept of Hebrew studies was established and Córdoba became the seat of Jewish scholarship ${ }^{28}$ (Image 1).

Image 1. Cantor Reading Passover Story in Moorish Spain, from a Fourteenth-Century Spanish Haggadah, Artist Unknown

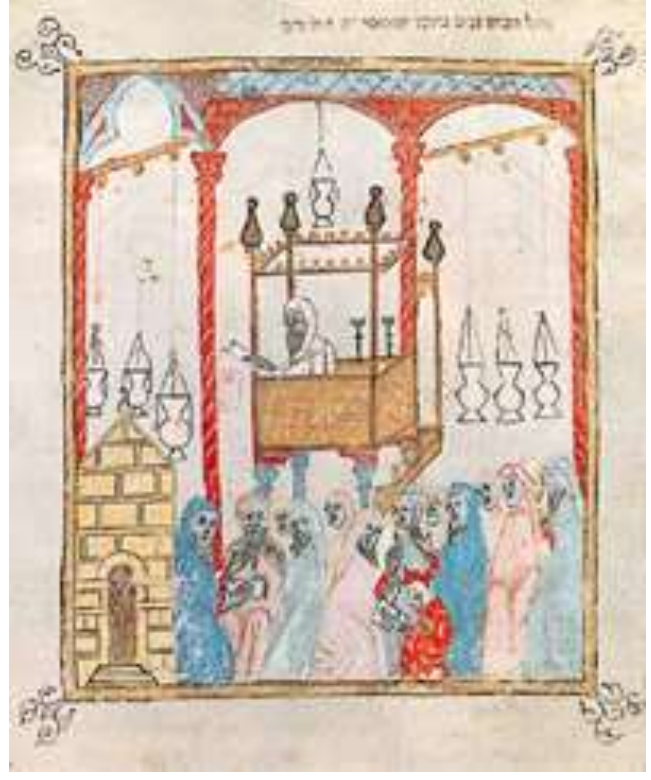

Efforts by Christians to regain political control of Hispania began shortly after the Muslim takeover. In 722 they gained a foothold in the northern most region of the Peninsula establishing the Kingdom of Asturias. ${ }^{29}$ In the early ninth century Charlemagne, eager to expand his kingdom, gained control of Aquitaine and pushed the Muslims further south, significantly strengthening the power of the Christian Church on the Peninsula. ${ }^{30}$ In the Middle Ages, the Pope, contending that the Muslim fight in Spain was as important as the Crusades in Jerusalem, extend the energy of the Crusades to the re-conquest of the Spain. By 1238 they had driven the Muslims to the southern part of the

27. Assis, The News of Spain: From Settlement to Expulsion, 12.

28. Nahum M. Sarna, "Hebrew and Bible Studies in Medieval Spain," in Sephardi Heritage, vol. 1, ed. R. D. Barnett (New York: Ktav Publishing House, Inc., 1971), 327.

29. Trudy Ring, Robert M. Salkin, and Sharon La Boda, International Dictionary of Historic Places: Southern Europe (Chicago: Fitzroy Dearborn Publishers, 1994-96), 170.

30. Barton Sholod, Charlemagne in Spain: The Cultural Legacy of Roncesvalles (Geneva: Droz, 1966), 39-44. 
Peninsula where they established the Kingdom of Granada where they remained for the next 200 years. ${ }^{31}$

While under Moorish rule the Iberian Peninsula was viewed as a refuge for Jews, but with the increasing political power of the Christian Church there was a gradual return to the persecution of the Jews. When King Alfonso VIII of Castile liberated Toledo from the Muslims at the Battle of Las Navas de Tolosa in 1212, the Crusaders also robbed and killed many Jews. ${ }^{32}$ In 1250 Pope Innocent IV issued a papal bull prohibiting the building of synagogues without permission, and disallowing proselytizing. It also forbade Jews from associating with Catholics and required all Jews to wear badges. ${ }^{33}$ Despite these setbacks, Jews and the remaining Muslims lived and work in relative peace and prosperity for the most part. By the late fourteenth century Jews in Spain numbered among the largest and most prosperous communities to be found anywhere in Europe.

In 1378 Ferrand Martinez, Archdeacon of Écija, began preaching antiSemitic sermons in Seville, admonishing his audiences to expel the Jews and demolish their synagogues. Although ordered by the archbishop and the king to stop harassing the Jews, Martinez, unperturbed, continued whipping up anti-Jewish sentiment for the next decade. On 6 June 1391 mobs attacked the Jewish community in Seville killing some 4,000 Jews. The attacks spread to Córdoba where the entire Jewish community was burned and every Jew slain before authorities could intercede, resulting in the death of more than 2,000. ${ }^{34}$ In other cities synagogues were converted into churches and the Jews that were not killed were baptized, either willingly or unwillingly. From there the rioting and killing spread throughout Spain. This series of horrific massacres marked the end of the Jewish golden era marking a real turning point in the history of the Iberian Peninsula. ${ }^{35}$

Jews in Spain and Portugal who converted to Christianity were called Conversos. Historians claim that by 1410 some 200,000 Jews had converted, leaving only around 100,000 openly practicing Jews on the Peninsula. Many of the Conversos adapted to Christianity and without the anti-Semitic restrictions achieved important positions in the government and even in the Church.

31. John Tolan, Europe and the Islamic World: A History (Princeton: Princeton University Press, 2013), 39-40.

32. Lynn Hunt, R. Pochia Hsia, Thomas R. Martin, Barbara H. Rosenwein, and Bonnie Smith, The Making of the West: Peoples and Cultures: A Concise History, Vol. I: To 1740, 2nd edition (New York: Bedford/St. Martin's, 2007), 391.

33. William H. Prescott, History of the Reign of Ferdinand and Isabella (New York: A. L. Burt, 1838), 515.

34. Henry Charles Lea, "Ferrand Martinez and the Massacres of 1391," in The American Historical Review 1, no. 2 (1896), 215-216.

35. The Jewish Encyclopedia, ed. Isidore Singer, vol. 11 (New York: Funk and Wagnalls, 1901), 497. 
Other Conversos continued to practice Judaism privately in their homes and were known as Crypto-Jews. ${ }^{36}$

In summer of 1411 Dominican Vincent Ferrer of Castile transformed a large synagogue in Toledo into the Church of Santa Maria La Blanca baptizing more than 4,000 Jews in that city. ${ }^{37}$ The hatred of the Jews became so acute and the complaints so plentiful that King Henry III of Castile was forced to prohibit Jews from the practice of lending money, a decision he later regretted when many of the Jews moved to other counties and he no longer received their heavy taxes. Other anti-Jewish laws were passed with the intention of further humiliating them and reducing them to poverty. They were not allowed to practice medicine or pharmacy, nor could they engage in the trade of wine, meat, bread and other goods. They were not allowed to socialize with Catholics and Jewish women had to wear long course garments. While these demeaning laws severely harmed Jewish communities, the entire country also suffered from the commercial and economic disruption that followed. By the mid-fifteenth century the hatred toward the Conversos outstripped that of the professing Jews, and many of their houses were burned and many were murdered. ${ }^{38}$

King Ferdinand II of Aragon and Queen Isabella of Castile were married in 1469, thereby uniting their kingdoms marking the beginning of the unification of Spain. Both were devout Catholics and well aware of the state of the Jewish controversy. During a visit to Seville in 1477 Isabella became convinced that Crypto-Jews were trying to re-convert the Conversos. So in 1478 the Monarchs requested a papal bull from Pope Sextus IV to establish an Inquisition. On 1 November 1478 the Pope issued Exigit Sinceras Devotionis Affectus establishing the Spanish Inquisition giving the Monarchs complete authority to name the inquisitors. ${ }^{39}$ With the goal of identifying and punishing Crypto-Jews, the first hearings of the Inquisition were held in Seville on 6 February 1481 and resulted in the execution of six people by burning. As the hearings continued the Pope expressed concern and threatened to recall the Inquisition, claiming that many faithful Catholics had been included in the executions based simply on the word of others, but Ferdinand threatened to make the Inquisition an independent initiative of the state and the Pope relented. ${ }^{40}$

36. Henry Kamen, The Spanish Inquisition (New Haven: Yale University Press, 1999), 10.

37. Carol Herselle Krinsky, Synagogues of Europe: Architecture, History, Meaning (Cambridge: MIT Press, 1985), 387-394.

38. The Jewish Encyclopedia, vol. 6, 498.

39. Edward Peters, Inquisition (New York: Free Press, 1988), 89.

40. Arnold H. Mathew, The Life and Times of Rodrigo Borgia (London: S. Paul \& Co., 1912), 52-53. 
Image 2. Spanish Inquisition; Woodcut by Johann Schoffer, 1508

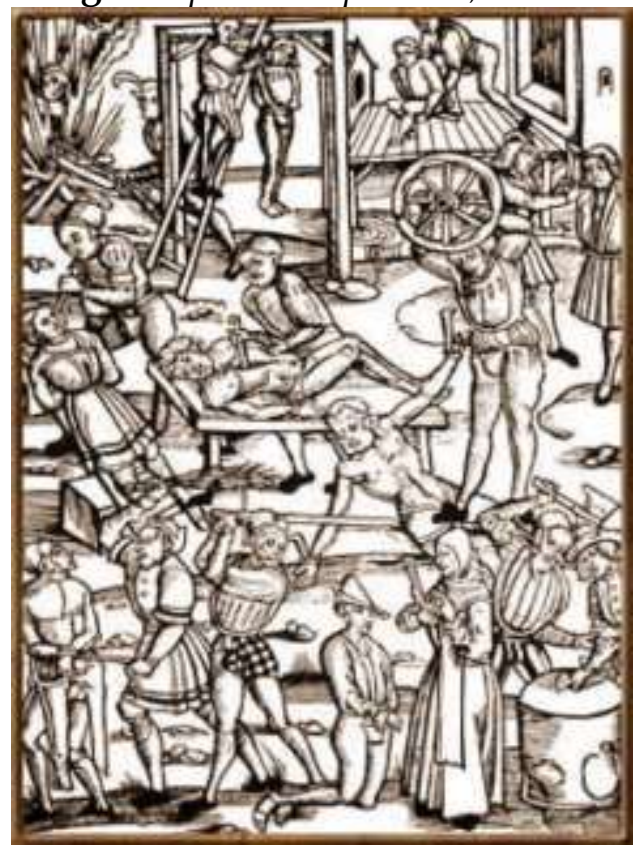

Despite all the efforts of the Inquisition, it was eventually determined to be inadequate to remedy the problem (Image 2). Therefore, on 31 March 1492 the Alhambra Decree, or Edict of Expulsion, was issued by the Monarchs ordering all practicing Jews to convert to Christianity or leave Spain by the end of July. Some scholars claim between 200,000 and 800,000 Jews left the Iberian Peninsula during this time. ${ }^{41}$ However, more recent scholars claim the real numbers are probably around 40,000 who chose to leave out of 80,000 practicing Jews and 200,000 Conversos, while another 40,000 chose to convert to Catholicism and remain. Meanwhile, it is estimate that around 2,000 Jews were executed through the efforts of the Inquisition between 1480 and 1530.42 Coincidently, the expulsion of the Jews came shortly after the fall of Granada on 2 January 1492, which ended the long presence of Moorish rule on the Iberian Peninsula. ${ }^{43}$

It is not known if members of John Baptist's family were executed as a result of the Inquisition; however, it is assumed that his family had converted to Christianity, at least in name, and that they were among the thousands who chose to immigrate to Italy in 1492.

41. Salo Wittmayer Baron, A Social and Religious History of the Jews: Christian Spain (New York: Columbia University Press, 1952), 170.

42. Kamen, The Spanish Inquisition, 29-31.

43. J. N. Hillgarth, The Spanish Kingdoms: 1250-1516. Volume II: 1410-1516, Castilian Hegemony (Oxford: Clarendon/Oxford University Press, 1978), 367-393. 


\section{Italy and the Renaissance}

Sephardic Jews leaving the Iberian Peninsula scattered to all parts of Europe as well as Northern Africa and the Middle East. However, due to the similarities between the Spanish and Italian languages many chose to settle in Italy. ${ }^{44}$ For musicians there were other attractions to Italy, chief among which was the exciting movement that we now called the renaissance. Following the fall of Constantinople to the Turks in 1453, many Greek scholars immigrated to Italy, attracted by the humanistic movement already spreading across Europe, thereby igniting a great revival in Greek art and culture. Italy had become a focal point for the arts during the fifteenth and sixteenth centuries. ${ }^{45}$

Rome had been a dominant force on the Italian Peninsula for ages, due to the influence of the Roman Church. However, following the death of Pope Leo $X$ in 1521 and the sack of Rome in 1527, its domination was significantly diminished. ${ }^{46}$ Meanwhile, Venice and other Northern Italian city-states had become important destination places for Jews escaping persecution, largely because they were located a safe distance from Rome and out of reach of the Popes who had generally remained hostile to Jews. ${ }^{47}$ Furthermore, Venice was fast becoming a center for the development of new musical styles, particularly the madrigal and the polychoral style. ${ }^{48}$

Not far from Venice somewhere in Northern Italy around the beginning of the sixteenth century, one of the most significant musical developments of the renaissance took place; the violin was invented. Its origin is shrouded in mystery due primarily to the fact that none of the earliest violins survived. ${ }^{49}$ Consequently, scholars turned to art for information about the early violin. Some of the earliest images are found in frescos of churches and palaces of Northern Italy near where the violin was invented. One of the earliest examples was painted by Benvenuto Garofalo or his assistant around 1505-08, and is found in the Palazzo di Ludovico il Moro in Ferrara. It depicts a bowed instrument with the distinct features of a violin. ${ }^{50}$ Another early example, a portion of which is shown in Image 3, is the magnificent fresco entitled Coro Degli Angel found in the dome of the Church of Santa Maria dei Miracoli in

44. Kamen, The Spanish Inquisition, 157.

45. Paul Oskar Kristeller, Renaissance Thought II: Papers on Humanism and the Arts (New York: Harper Torchbooks, 1965), 178.

46. Ferdinand Gregorovius, History of the City of Rome in the Middle Ages, trans. Annie Hamilton, vol. VIII part 2 (London: George Bell \& Sons, 1906), 534-543.

47. The Jewish Encyclopedia, vol. 10, 126-27.

48. Blanche Bangwere, Music History During the Renaissance Period, 1520-1550 (Westport, CT: Praeger Publishers, 2004), 264.

49. Holman, Four and Twenty Fiddlers, 1.

50. Mary Remnant, Musical Instruments of the West (London: Batsford, 1978), 45. 
Saronno. It was painted by Gaudenzio Ferrari in 1534-35 and depicts angels playing a violin (center right), cello (lower right) and viola (upper left). ${ }^{51}$

Image 3. Coro Degli Angeli, by Gaudenzio Ferrari, in Church of Santa Maria dei Miracoli, Saronno, Italy

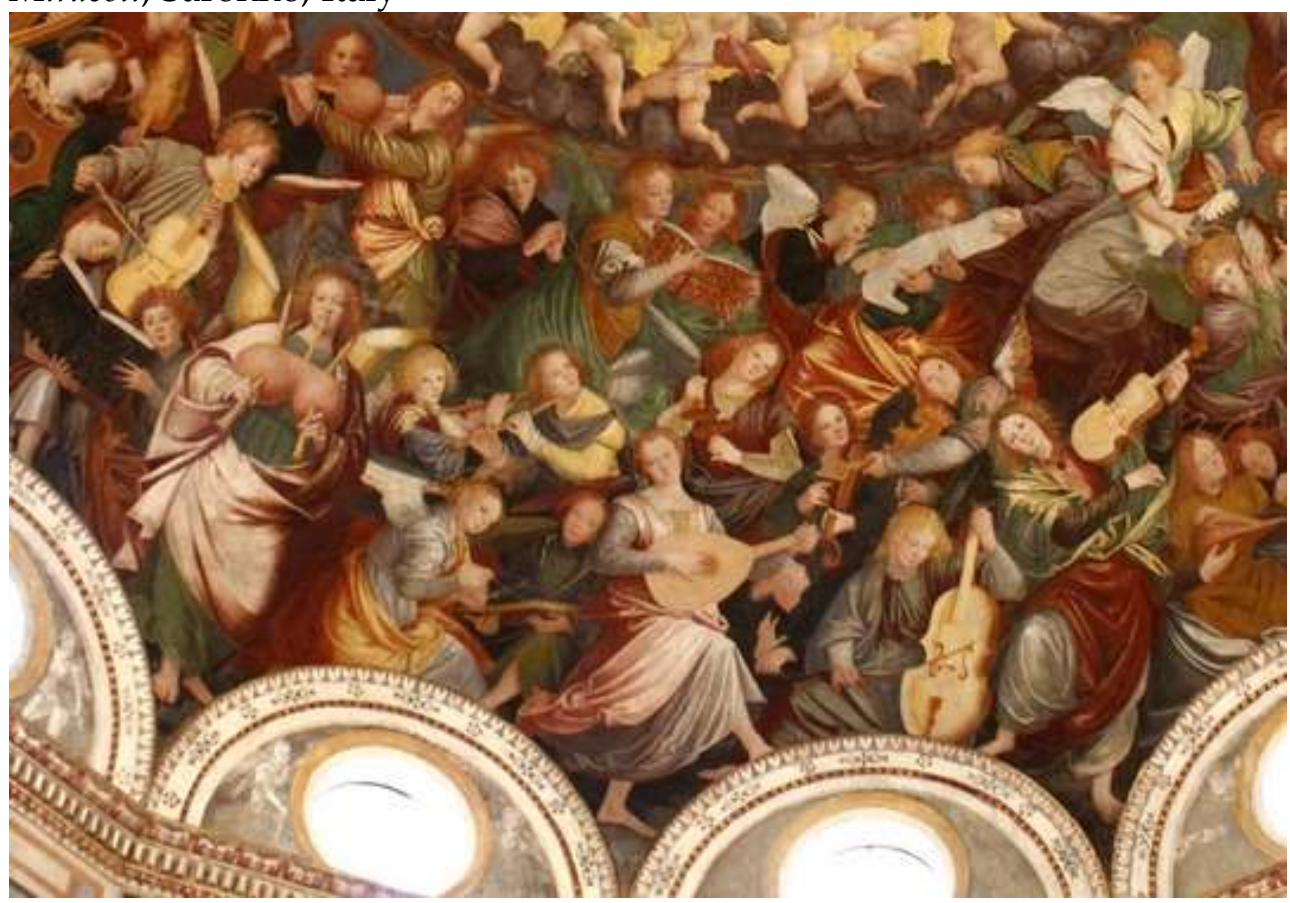

Saronno is located north of Milan about 15 kilometers east of Busto Arsizio where John Baptist and his family settled, and where the Lupo brothers were likely born and grew up.

The immediate predecessor of the violin was the viola da gamba, which was long thought to have evolved in Spain from the medieval vielle in the fifteenth century. ${ }^{52}$ More recent research, however, indicates that it probably developed in the late fifteenth century when the Spanish started bowing the guitar-like vihuela in a vertical position, influenced by the Arabic rabab. The viola da gamba was then either brought to Rome by the entourage of Rodrigo de Borgia when he became Pope Alexander VI in 1492, or bought to Northern Italy by the Sephardic Jews escaping the Inquisition. ${ }^{53}$ Either way, the viola da gamba was well established as the primary stringed instrument in Italy by the late fifteenth century.

51. Emmanuel Winternitz, "Early Violins in Paintings by Gaudenzio Ferrari and his School," in Musical Instruments and Their Symbolism in Western Art (London: W. W. Norton \& Co., 1967), 99-109.

52. Thruston Dart, "Viols," in Musical Instruments through the Ages, ed. A. Baines (Baltimore: Penguin Books, 1961), 184.

53. Holman, Four and Twenty Fiddlers, 14. 
The viola da gamba had frets, six strings tuned in fourths-except for a third between the two middle strings-and it was played between the legs (gamba). It quickly became the favorite stringed instrument of elite society, and was usually found in consorts, that is, group of like instruments of different sizes capable of playing the vocal ranges of polyphonic choral music. Peter Holman claims that Isabella d'Este, Marchesa of Mantua, was likely responsible for the development of the viol consort when she ordered viols of different sizes near the end of the fifteenth century. Prior to that time stringed instruments were generally solo instrument used primarily to accompany dance. ${ }^{54}$

The violin was not a direct descendant of the viola da gamba; on the contrary, its technology is quite different. It has no frets, is tuned in fifths, had a sounding post to augment its sound, and had three strings instead of six-although a fourth string was soon added. It likely inherited its tuning from the lyra da braccio, a medieval instrument descended from the vielle, and was played on the arm (braccio) like both the lyra da braccio and the vielle. The violin was more difficult to play, in part because it had no frets. It was adopted by professionals while amateurs continued to play the viola da gamba. With no frets violinists were capable of playing more expressively and more in tune, and the violin was a consort instrument from the beginning. It was shaped much like the lyra da braccio and somewhat similar to the Spanish vihuela while the viola da gamba is distinguished by its sloping shoulders. Image 4 compares the Spanish vihuela, viola da gamba, lyra da braccio and violin. The two drone strings on the left side of the lyra da braccio were not carried over to the violin.

Image 4. Comparison of the Vihuela, Viola da Gamba, Lyra da Braccio and Violin

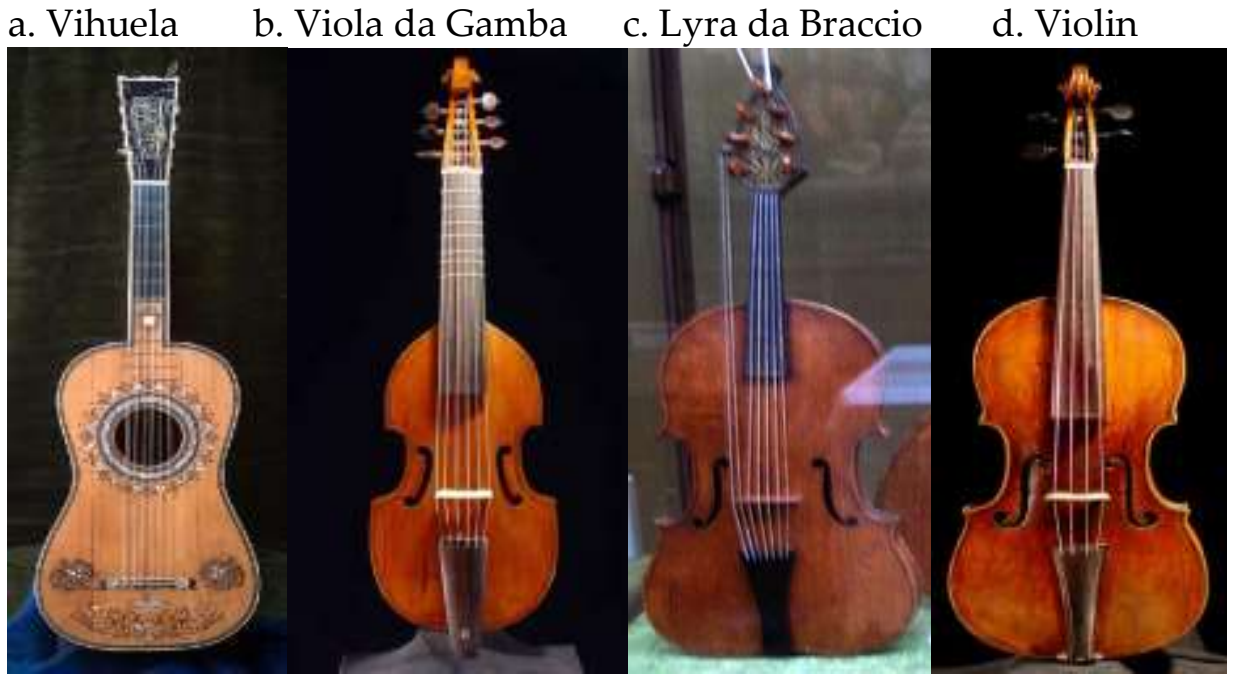

54. Ibid., 16-17. 
In addition to the musical attractions, Jewish immigrants to Italy were also attracted by its social and humanitarian advantages. At a time when most European countries were expelling Jews, the Republic of Venice under, the leadership of Doge Leonardo Loredon and his council, decided in 1516 not to expel Jews, but rather to establish the first Jewish ghetto in Europe. ${ }^{55}$ As a result, Jews from other European countries were drawn to Venice, including Sephardic Jews from Portugal and Spain. Also, Jews from other regions of Italy began to relocate to Venice. The Bassano family of wind instrument players, from which the first five musicians were hired for the English court, reportedly left the Kingdom of Sicily around the end of the fifteenth century when that kingdom expelled its Jews, settling in Bassano del grappa, a village in Northern Italy, from which they took their name. Then in the early sixteenth century they were drawn to Venice where several of them found work in the Doge's palace. ${ }^{56}$ It is not surprising, then, that the Lupos would eventually relocate from Busto Arsizio to Venice.

The concentration of musical activities and world-class musicians in Venice did not go unnoticed when Cromwell set about to fulfill Henry VIII's charge to find the best musicians in the world for the English court. His agent in Venice, an Englishman by the name of Edmond Harvel who was living in Venice at the time, wrote to Cromwell assuring him that the Bassanos were among the finest wind instrument players in the world when he hired them in May of $1540 .{ }^{57}$ He must have had equal confidence in the Lupo string players, for a month later he hired them and their string colleagues. They were placed on the payroll effective 1 May 1540, although they did not begin their service at the court until November. The backdating most likely was done in order to cover their relocation expenses. ${ }^{58}$

We do not know if the Lupos practiced Judaism openly while in Italy or not; however, in England they would be required to be members of their local parish churches. In England the term New Christian corresponded to the Spanish term Converso while the more pejorative term Marrano was the English equivalent to the Spanish term Crypto-Jew.

\section{Jewish Life in England Prior to 1540}

The history of Jewish life in England prior to the arrival of the Lupos was somewhat similar to that on the Iberian Peninsula, except that no records have been found regarding Jews living in England before the arrival of William the

55. The Jewish Encyclopedia, vol. 12, 409-410.

56. A Biographical Dictionary of English Court Musicians, vol. I, 85-86.

57. Holman, Four and Twenty Fiddlers, 78-81.

58. A Biographical Dictionary of English Court Musicians, vol. II, 744-745. 
Conqueror in 1066. William reportedly brought Jews from Normandy for the purpose of establishing a coinage system so that feudal dues could be paid in coin rather than goods. Under his son, Henry I, Jews were allowed to move freely about the country and were considered, along with their property, to belong to the King. ${ }^{59}$ Under King Stephen the Jews did not fare as well, for it was during this time that the charge of blood libel against Jews was first recorded.$^{60}$ Later, when Henry II sought to raise money to fight the crusades, he demanded a quarter of the Jewish chattels while requiring only a tithe from the rest of the country. During this process it was learned in 1186 that Jews owned a quarter of all personal property in England while they constituted only a fraction of the population. ${ }^{61}$

When Richard I became King in 1189 some Jewish leaders came to pay homage but were repulsed. Rumors spread that the king had ordered the Jews massacred and, consequently, many were killed. Richard was upset by the massacre but no one was ever punished, and after he left on his crusade many more Jews were massacred. Anti-Semitism spread to other cities and towns throughout England, and at York on 16-17 March 1190 a mob, many being motivated by the fact that they owed money to the Jewish bankers, attacked the castle where a number of the city's Jews had sought refuge. Seeing no way out many took their own lives rather than starve while the rest were slain. Some efforts were taken to punish the offenders but most fled to Scotland and escaped punishment. ${ }^{62}$

In an attempt to raise funds to fight his war with Wales in the thirteenth century, King Edward I demanded additional taxes of the Jews, and when they were unable to meet his demands they were persecuted, imprisoned, or executed. During his reign anti-Semitism continued to increase until legislation was eventually passed in 1290 to expel all Jews from England. ${ }^{63}$ An estimated 2,000 Jews left England for other European countries with only what they could carry. ${ }^{64}$

59. The Jewish Encyclopedia, vol. 5, 161-162.

60. Anthony Julius, Trials of the Diaspora: A History of Anti-Semitism in England (Oxford: Oxford University Press, 2010), 153.

61. The Jewish Encyclopedia, vol. 5, 163-164.

62. Ibid., 165-167.

63. Michael Prestwich, Edward I (New Haven: Yale University Press, 1997), 343.

64. Robin R. Mundill, England's Jewish Solution: Experiment and Expulsion (Cambridge: Cambridge University Press, 2004), 1262-1290. 
Image 5. Expulsion of Jews from England, 1290, by Unknown Artist

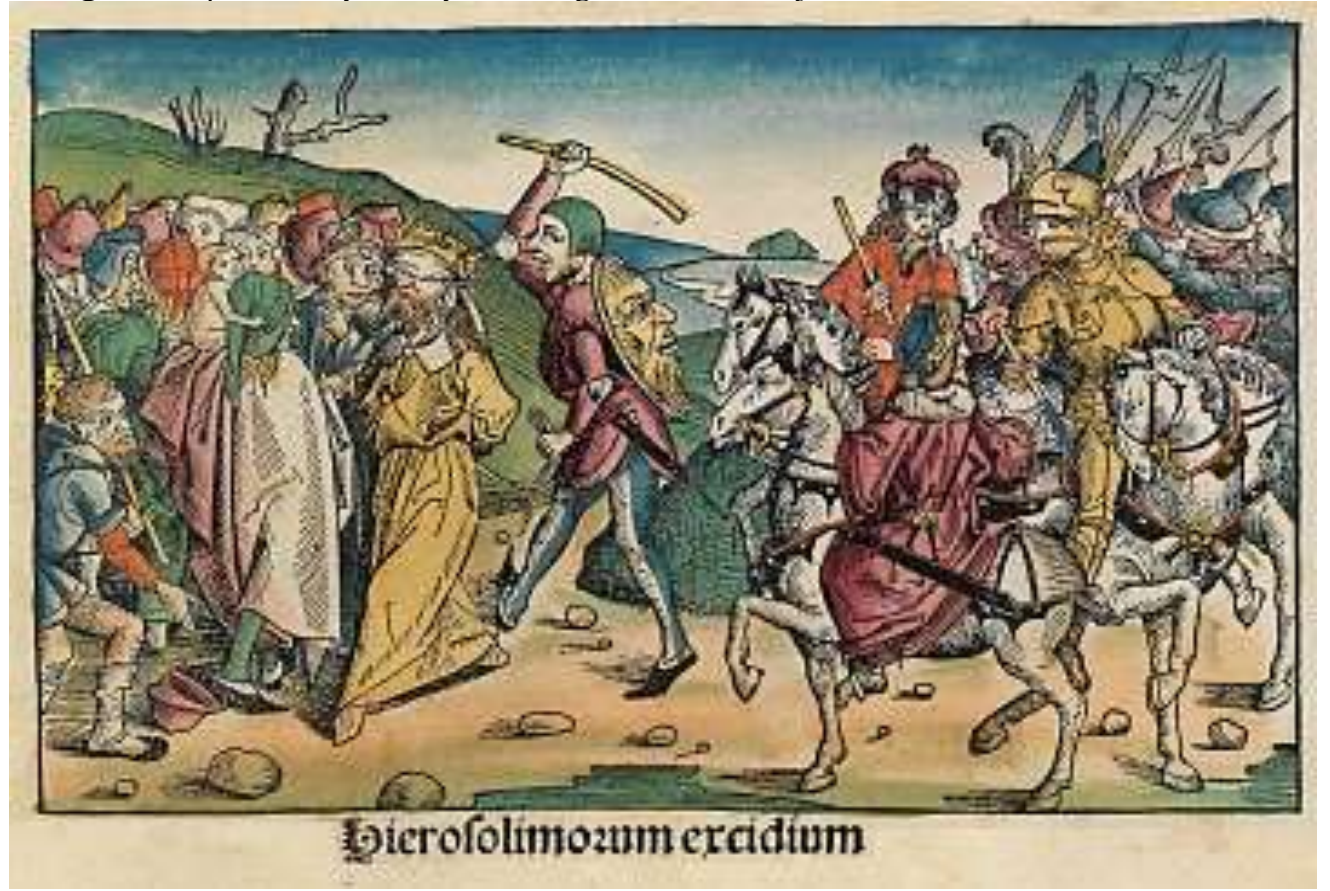

After the expulsion there was no official record of Jews in England until the Resettlement of 1655 except for the Domus Conversorum, a house in London established by Henry III in 1232 to house converted Jews (Image 5). Some Jews remained within its precincts until 1551 or later. ${ }^{65}$ Attempts were made to revoke the expulsion as early as 1310 but to no avail; however, some Jews apparently managed to come back because there was a complaint in 1376 that Jews were trading in London pretending to be Lombardi from the Italian Peninsula. ${ }^{66}$

\section{Henry VIII}

This was the state of affairs in England when Henry VIII became king on 21 April 1509, some two months shy of his eighteenth birthday. His older brother Philip was destined to be king but died when Henry was 16. His father had intended young Henry to enter the Church, and as such provided him with the finest education in the classical, humanist manner. He was fluent in French, English and Latin and had a working knowledge of Italian, Spanish and Greek. He was inventive and experimented with mechanics and technology, was

65. The Jewish Encyclopedia, vol. 5, 165.

66. Ibid., 171. 
passionate about astronomy, and it was said he was learned in all the sciences. Erasmus, in fact, called him a universal genius. ${ }^{67}$

When Henry was eight it was clear he had inherited the musical aptitude that ran in his family and his father gave him a lute. Not much is known about his early musical training but in adulthood he was passionate about music, and it is said that music dominated his life. Wherever he went, in public or private, music was heard - at state occasions, at mealtimes, upon entering or exiting a room, while dancing, whatever the occasion. Visitors to the court were ecstatic about the music they heard. Henry could read music at sight and was considered a fair composer. Pastime with Good Company is one of his compositions still performed today (Image 6). He was reported to have a rather good tenor voice and could play almost any instrument. ${ }^{68}$

Image 6. Pastime with Good Company, by Henry VIII, ca. 1513 (original score in British Library, London)

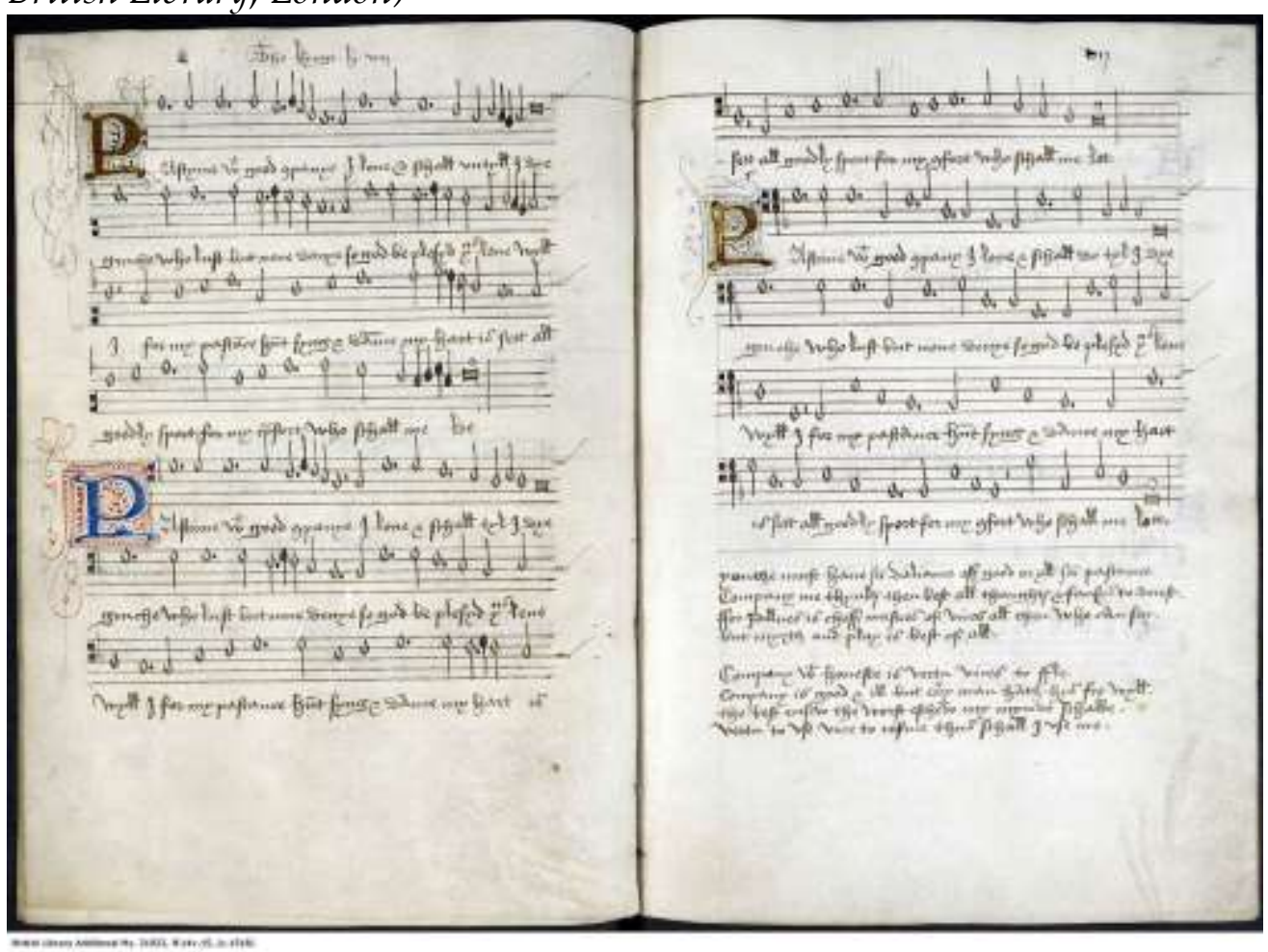

No doubt Henry's extraordinary education and love of music were significant factors in his desire for quality music at the court. To clarify, however, his desire for quality music was in reference to secular music and not to sacred music. At that time secular music at the court was a holdover from the fifteenth century and a bit outdated. There were consorts of wind instruments at the

67. Alison Weir, Henry VIII (New York: Random House, Inc./Ballantine Books, 2008), 8. 68. Ibid., 127. 
court but no string consort. ${ }^{69}$ Sacred music, by contrast, was centered in the Chapel Royal and had a long and distinguished history of excellence. It was one of the most exciting centers of sacred music in Europe at the time. ${ }^{70}$ In 1510 Sebastian Guistinian, the Venetian Ambassador to England, heard the choir at the Royal Chapel and reported that the voices were more divine than human, and that he thought them to have no equals in the world..$^{71}$

One of the most significant developments during Henry's reign was the separation of the English Church from the Roman Catholic Church, an action not so much based on religious grounds as on political grounds. In 1527, desperate to have a male heir, Henry asked Pope Clement VII for an annulment of his marriage to Catherine of Aragon so he could marry Anne Boleyn. When the Pope denied his request he turned to the bishop of Canterbury and asked him to grant the annulment. The bishop, having little choice in the matter, granted it. ${ }^{72}$ After Henry married Anne Boleyn the Pope pronounced the marriage invalid. Henry responded by asking the English Parliament to pass a series of acts culminating in the Act of Supremacy of 1534 declaring Henry the Supreme Head on earth of the Church of England. ${ }^{73}$

Following the separation of the English Church from Rome Henry was obsessed with the fear that those around him might have a loyalty to the Pope and start a rebellion. At some point he came to the realization that he would not need to worry that Jewish servants might bring with them an allegiance to the Pope. Thus, he began quietly recruiting Jews to England despite the laws prohibiting it, and word spread fast that England was a place of refuge for Jews. ${ }^{74}$

\section{The Lupos at the English Court}

With the arrival of the six new viol players from Venice, Henry had a viol consort (Image 7). The painting below of an anonymous group of musicians illustrates the different sizes of viols that make up a consort.

69. Holman, Twenty and Four Fiddlers, 60-61.

70. Harold N. Hillebrand, "The Early History of the Chapel Royal," in Modern Philology 18, no. 5 (1920), 233.

71. Weir, Henry VIII, 128.

72. Roger Scruton, A Dictionary of Political Thought (New York: Macmillan Publishers, 1996), 470.

73. Documents of the English Reformation, ed. Gerald Bray (Cambridge: James Clarke \& Co., 2004), 115.

74. Holman, Four and Twenty Fiddlers, 86-87. 
Image 7. Viol Consort, by Unknown Artist, ca. Sixteenth Century

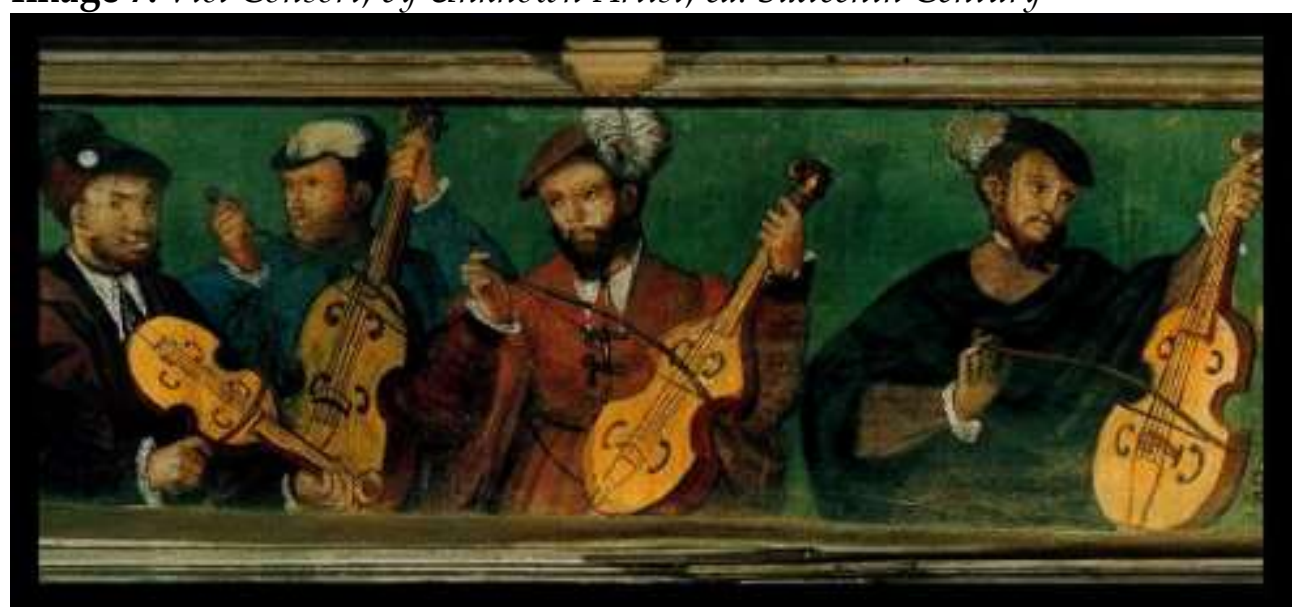

Ambrose's brother Romano died while they were imprisoned briefly in 1542 and was survived by his widow Martha de Milano. ${ }^{75}$ It is not known exactly when Alexandro died or otherwise left the country due to a break in court records. He was there in September 1544 when the records stopped, but his name was absent from the list of those playing at the funeral of Henry VIII on 16 February 1546/7 when the records resumed. ${ }^{76}$ Ambrose continued to perform in the string consort until his death in 1591. He performed at the funeral of Henry VIII, the coronation of Edward VI on 20 February 1546/7, the funeral of Edward VI on 8 August 1553, and the coronation of Elizabeth I on 17 November 1558. His wife, Lucia, did not move to London with him in 1540 but remaining in Italy instead. ${ }^{77}$

Many records of the musicians are routine facts of accounting but a few reveal their human side. For instance, in February of 1565 Ambrose was brought before a Consistory body of the French Church in London and accused of having improper sexual relations with his French maid, Marguerite de Rockus. Then in 1572 the records indicate he applied for a separation from his wife Lucia in Italy and a license to marry an English woman. Permission was granted, provided he first go to Italy and find his wife. Ambrose apparently disregarded the Consistory body's request and was married a month later, claiming he had evidence that his wife had died. The Consistory body later learned that his claim was untrue, and once again he was brought before the board. This time he told them he had gone to Italy and found his wife, but that she refused to come to London because of the religion. ${ }^{78}$

75. A Biographical Dictionary of English Court Musicians 1485-1714, Vol. II, 749.

76. Holman, Four and Twenty Fiddlers, 24.

77. A Biographical Dictionary of English Court Musicians 1485-1714, Vol. II, 746.

78. Ibid. 
Over the course of time most of the Jewish musicians had become well integrated into English society, and some were quite financially secure. Evidence indicates that Ambrose was among the wealthy according to sixteenth century standards. He was assessed a fee of $4 \mathrm{~d}$ by his parish Church of St. Alphage for the quarterly pay of the clerk, an amount that would only have been assessed on the wealthiest members of the parish. ${ }^{79}$ He died and was buried on 13 February 1591 at St. Alphage Church after 51 years of service to the kings and queens of England in the string consort, the longest tenure of any member of the string consort. In his estate he left 20s to St Alphage Church to be distributed to the poor. ${ }^{80}$ Yet another indicator that the Lupo family was wealthy is the fact that one of his grandsons, Albiano, son of Peter, owned a share of the Virginia Company. He moved to the Jamestown Colony in 1610 and he paid the passage for five other people. ${ }^{81}$ In Virginia he and his wife, Elizabeth, owned 400 choice acres of land on the Chesapeake Bay waterfront in what is now Hampton, VA. Only the wealthy could afford to own a share of the Virginia Company, or to transport five additional people to the colony. ${ }^{82}$

After Elizabeth I became Queen on 17 November 1558 the string consort became known as the violin consort. It is not known just how or when the change occurred, but it was probably a gradual change. In the early years of the string consort the viol was used for polyphonic music while the violin was used primarily for dance, and since Elizabeth loved to dance, it stands to reason that the violin would become more important during her reign. ${ }^{83}$ In Image 8, the painting by an unknown artist depicts two soprano violins and a bass violin (cello) on the left accompanying the Queen and her partner in a dance.

79. Holman, Four and Twenty Fiddlers, 24.

80. A Biographical Dictionary of English Court Musicians 1485-1714, Vol. II, 746.

81. Peter Wilson Coldham, Complete List of Emigrants 1607-1660 (Baltimore: Genealogical Publishing Co. Inc.), 44.

82. Nell Marion Nugent, Cavaliers and Pioneers, vol. 1 (Richmond: The Library of Virginia, 1992), xxvii-xxviii

83. Holman, Four and Twenty Fiddlers, 87-89. 
Image 8. Queen Elizabeth I Dancing with Partner, by Unknown Artist, ca. Late Sixteenth Century

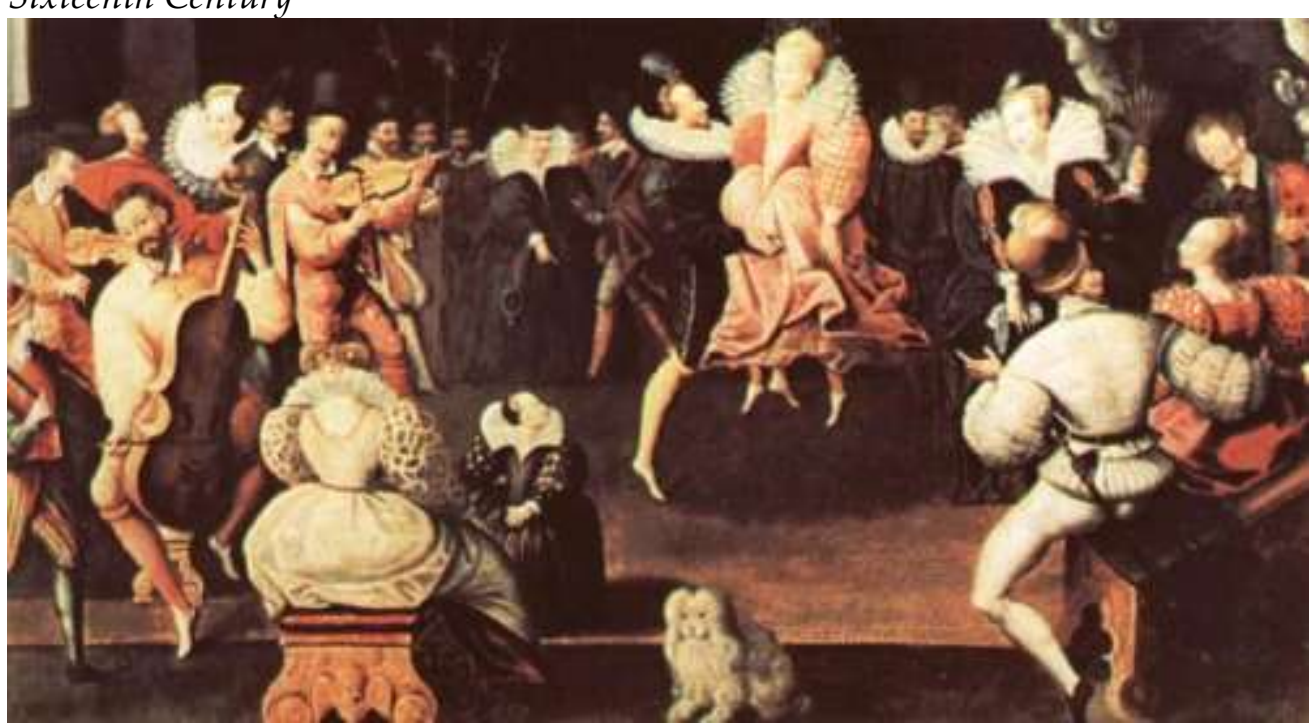

Ambrose and Lucia had two sons, Peter and Joseph, born about 1535 and 1537 respectively, who followed in their father's footsteps in the string consort. They joined the musicians' guild in Antwerp, Peter on 17 January 1555 and Joseph on 20 August 1557, where they were listed as born in Venice, sons of Ambrose ${ }^{84}$ Peter married Koven (or Katherine) in Antwerp where their first child, Elizabeth, was born. They moved to London sometime before January 1562/3 when their second child, Pheybe, was baptized at the Church of St. Botolph without Aldgate. Two weeks after the birth of their fourth child on 29 September 1575 his wife died. A month later Peter married Katherine Wickers at St. Botolph's and together they had at least six children. Peter joined the string consort on 25 March 1567. He performed for Queen Elizabeth's funeral and continued in the service of King James I. He was granted a warrant on 13 February 1606/7 from the Privy Council for $£ 20$. He died in 1608 after 41 years in the string consort and was likely buried at Greenwich. ${ }^{85}$

Joseph was married by 1571 to Laura Bassano, daughter of Alvise and Johane Bassano. Alvise was one of the five Bassano brothers also hired at the court in 1540. This is one of several instances of intermarriage between these two musician families over the years. Joseph and Laura were living with her brother Augustine on Hart Street in the parish Church of St. Olave in 1571 where a baptism was dated August 7 listing a Thomas s(on) [of] Basanew. This is assumed to be Thomas Lupo, son of Joseph and Laura Lupo and that the scribe confused the last names because they were living in the home of Augustine Bassano. Joseph joined the string consort on 23 September 1563 and also

84. Ibid., 81.

85. A Biographical Dictionary of English Court Musicians 1485-1714, vol. II, 747-749. 
performed at Queen Elizabeth's funeral and continued in the service of King James I. He was buried at Richmond on 23 April 1616.86

Peter and Joseph both had sons named Thomas and both followed the family tradition and joined the string consort. Joseph's son was known as Thomas the Elder (or I) while Peter's son was known as Thomas the Younger (or II). Both were composers as well as performers, and their compositions, along with those of other Lupo composers, constitute a significant body of works. ${ }^{87}$ Thomas I joined the violin consort on 26 January 1587/8 when he was 20 years of age. He, too, performed for the funeral of Queen Elizabeth, the coronation and funeral of James I, and then continued in the service of King Charles. In 1610 he composed music for two of Ben Jonson's masques, entitled Oberon and Love Freed from Ignorance and Folly, and also for Thomas Campion's Lord's Masque in 1612. He was appointed to the household of Henry, Prince of Wales, in 1610 where he served until the prince died in $1612 .{ }^{8}$

When Charles was designated Prince of Wales in 1619 Thomas returned to the prince's household, although only after he had resigned his performance position in the violin consort and accepted a new position as composer for the violins. At the prince's court Thomas and his colleagues created some of the most innovative and significant music to be found anywhere at that time. ${ }^{89}$ When Charles became king following the death of his father in May 1625, he combined the musicians of his previous household with those at the king's court. It is said that King Charles, himself a proficient musician, would occasionally join the musicians on bass viol..$^{90}$ Thomas was buried at Richmond on 23 April 1628. ${ }^{91}$

Thomas the Younger was baptized at St. Botolph's on 7 June 1577 and began his service in the violin consort in 1598. He played at Queen Elizabeth's funeral, the coronation and funeral of James I and the coronation of Charles. He continued in the consort until it was disbanded in 1642. Like his cousin, he played at the Inns of Court masque, The Triumph of Peace. He was a charter member of the Corporation of Musick in Westminster. He signed an acquittance for $£ 6$ 13s 4d from Cromwell's Committee of the Revenue on 5 April 1647.92 The date of his death is unknown.

Horatio, son of Joseph, was baptized on 5 November 1583 at St. Olave Church on Hart Street. He was employed from July 1607 to April 1608 in the

86. Ibid.

87. Holman, Four and Twenty Fiddlers, 90-100.

88. A Biographical Dictionary of English Court Musicians 1485-1714, vol. II, 750-751.

89. Ibid.

90. Thomas Lupo, The Five-Part Consort Music, vol. 1, ed. Richard Charteris (London: Fretworks Editions, 1997), iv.

91. A Biographical Dictionary of English Court Musicians 1485-1714, vol. II, 752.

92. Ibid., 752-753. 
household of Thomas Sackville, Earl of Dorset, and then joined the violin consort on 10 February 1611/12, a position he held for the remainder of his life. He was married first to Mary Stoyre and second to Sarah Wallis. He died in October 1626 and was buried at St. Martin-in-the-Fields. ${ }^{93}$

Theophilus, son of Thomas I, was the last Lupo to join the violin consort, replacing his father upon his death in spring 1627/8. However, for some unexplained reason there was a delay of a little more than a year in his official appointment, which did not occur until 6 May 1629, at which time he received payment for arrears. He continued in the violin consort until it was disbanded in 1642. He also played in the Inns of Court masque. Not much is known about him after the consort was disbanded except that he was assigned $£ 10$ by the Committee of the Revenue on 4 May 1644 and another $£ 613 \mathrm{~s} 4 \mathrm{~d}$ on 31 December 1649. He was buried at St. Giles Cripplegate Church on 29 July $1650 .{ }^{94}$

There were Lupo musicians in the English string consort over its entire 102-year history, and from January 1587/8 until February 1590/1 four of the six consort members were Lupos. ${ }^{95}$ Table 1 lists the Lupo musicians who served in the string consort by generation and years of service.

Table 1. Lupo Musicians in the String Consort

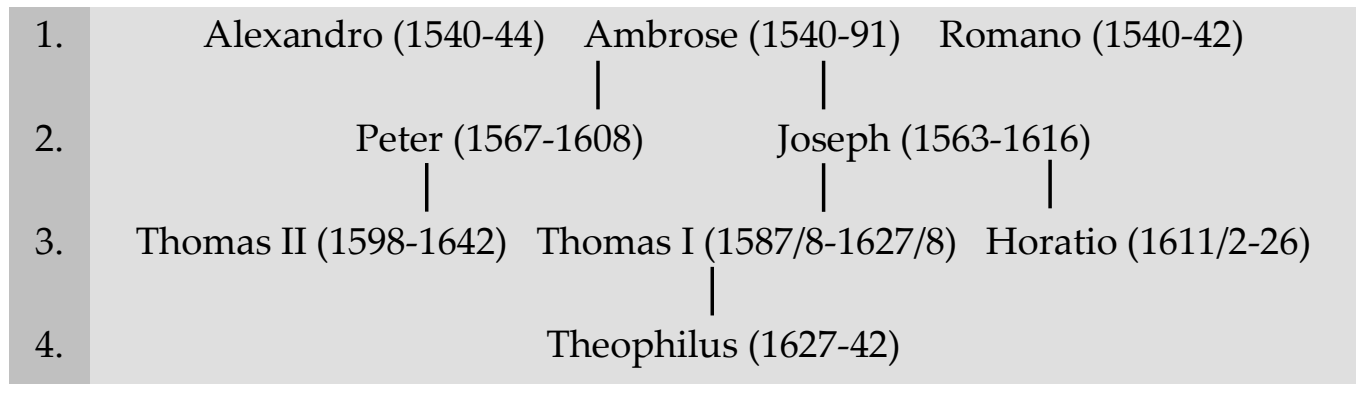

The musicians interacted daily with the royal family and by doing so developed a deep sense of mutual respect for each other. On special occasions they even exchanged gifts. For instance, all six of the new viol players received a New Year's gift of $£ 6$ from the king in 1643/4. ${ }^{96}$ On New Year's Day of 1573/4 Ambrose gave Queen Elizabeth a drinking glass with the queen's arms etched in the bottom, in a case of painted leather. Another year he gave her a pair of perfumed gloves in a leather chest. ${ }^{97}$ In the last year of his life the queen issued a lease in reversion of lands in the value of $£ 20$ per year to Ambrose as one of

93. Ibid., 747.

94. Ibid., 750.

95. Holman, Four and Twenty Fiddlers, 108.

96. A Biographical Dictionary of English Court Musicians 1485-1714, Vol. II, 746.

97. Ibid., 745-746. 
the eldest of her Majesty's musicians for the viols. ${ }^{98}$ In 1597/8 Joseph gave the queen a pair of perfumed gloves on New Year's Day, and another pair in 1600/1. And on 13 January 1600/1 she gave him a gift of $£ 200$ for his long and faithful service. ${ }^{99}$ These are but a few of the many gifts exchanged over the years. It is not surprising, then, that all of the Lupo musicians continued their service in the string consort until retirement or death. Throughout the history of the string consort ten of its members served tenures of 40 or more years, and five of those were Lupos. ${ }^{100}$

Several of the Lupos were composers as well as performers and as such left us a sizable body of works, mostly for strings. Thomas I was the most prolific, with his most significant works coming after he returned to the household of Charles, Prince of Wales, in 1617. Charles had gathered an outstanding group of composers, which included, Orlando Gibbons, Alfonzo Ferrabosco the Younger, John Coperario, and others, in addition to Thomas. ${ }^{101}$ It was there that they began to combine elements of the Italian fantasia, ricercar, canzona and toccata to create a new form that they called the English fantasia. ${ }^{102}$

Originally the Italian fantasia was an instrumental work patterned after the polyphonic motet, but without words. Its name came from the fact that it was strictly something from the fantasy of the mind of the composer who created it. It usually began with a polyphonic first section, followed by a homophonic middle, generally scored for fewer instruments, and followed by another polyphonic section utilizing all the instruments. ${ }^{103}$ The English fantasia retained the imitative polyphony of the Italian fantasia but incorporated patterned figuration heavily dependent on rhythmic consistency and abstract linear interaction. It also differed from the Italian fantasy by bringing back materials from the first section in the third section. These new developments marked the final separation of instrumental music from vocal music. The English fantasia exerted a strong influence on the direction of instrumental music and the development of new baroque forms, such as the fugue, prelude, invention, and more. It was generally written for consorts of instruments; however, it was during this time that composers also began to compose fantasias for mixed instrumental groups, or broken consorts. ${ }^{104}$

98. Holman, Four and Twenty Fiddlers, 24.

99. A Biographical Dictionary of English Court Musicians 1485-1714, Vol. II, 748.

100. Holman, Four and Twenty Fiddlers, 438-39.

101. Ibid., 212-13.

102. Gustave Reese, Music in the Renaissance, 2nd edition (New York: W. W. Norton \& Co., Inc., 1959), 870-874.

103. Christopher D. S. Field, et al., "Fantasia," in Grove Music Online, Oxford Music Online, Oxford University Press.

104. Manfred F. Bukofzer, Music in the Baroque Era (New York: W. W. Norton \& Co., 1947), 73-74. 
Thomas I composed dances, airs, and music for masques, but mostly he composed fantasias. He wrote many two-, three- and four-part fantasias that are generally considered to be experimental; however, his five- and six-part fantasias are considered significant works. He was strongly influenced by the Italian madrigal, to the extent that some of his fantasias were set to Italian texts and have Italian titles, but remain instrumental music without texts. ${ }^{105}$

The five-part English Fantasia (VdGS\#4) ${ }^{106}$ was composed by Thomas I and demonstrates many of the unique attributes of the English fantasia. It was likely composed at the court of Prince Charles sometime after 1619. ${ }^{107}$ Although it is an early baroque work, it retains the modal signature of Dorian; however, the prevalent use of B-flats and C-sharps brings it in line with the more modern tonality of $\mathrm{D}$ minor. It consists of three large sections delineated by strong cadences without double bars and repeat signs as would be expected in dance movements of the period. Its texture consists primarily of imitative polyphony with modest amounts of homophony, particularly in the second and third sections.

The first section begins with a statement of the subject in the opening five measures of the alto, followed by a counter subject in measures seven through ten. The subject is imitated in the soprano beginning in measure two, and again two measures after that in the first tenor, all beginning on tonic. The next statement of the subject occurs four measures later in the bass. This fantasia is particularly interesting because the counter subject that follows the subject in the alto beginning in measure seven is first stated in measure three in the second tenor, followed by a variant of the subject beginning in measure six, in reverse order from the rest of the statements. Once all parts have presented the subject and counter subject, they lead to an elided cadence on D major in measure 16, followed by 10 more measures of fragmented statements of the subject and counter subject before leading to a strong cadence on D major in measure 26 to end the first section.

The second section is scored thinner, creating a lighter texture for contrast. The melodic material is derived from the subject and counter subject of the first section, fragmented and imitated at a distance of one beat in stretto fashion to further increase tension. Tonal contrast is created by a modulation to $\mathrm{G}$ major confirmed by a strong cadence in measure 59 to end the section.

105. Peter Holman, "Thomas Lupo" under "Lupo family," in Grove Music Online, Oxford University Press.

106. Thomas Lupo, Fantasia for Five-part String Consort (VdGS\#4), IMSLP.com, International Music Score Library Project. To view the score click here; to listen to the score click here.

107. Richard Charteris, "A Rediscovered Source of English Consort Music," in Chelys 5 (1973-74), 3-5. 
The third section begins with a homophonic fanfare-like motive in the top two parts, imitated one beat later in the first tenor. While this motive sounds fresh, it has its rhythmic origin in the counter subject. It continues through the next 10 measures modulating back to the home key. After an elided cadence to $\mathrm{D}$ in measure 68, the counter subject from the first section returns in the bass and is imitated in the other parts leading to a strong cadence on D major in measure 84 . At that point the piece could end, but instead the composer repeats the third section, beginning with the fanfare-like motive in bold homophonic fashion, followed by another imitative section based on the counter subject leading to a final cadence on D Major.

This fantasia demonstrates the concept of return by bringing back the counter subject from the first section in the third section. This return of earlier material served as the model for the recapitulation of later periods. Also noteworthy is the fact that in this section the subject and counter subject are structured as an embryonic fugal statement and episode. These are some of the innovative concepts that were indeed crucial to the development of the baroque fugue and other forms.

\section{Conclusion}

After tracing the incredible journey of one family of musicians through a century and a half of trials, tribulations and triumphs, the original questions remain. Why were the Lupos recruited to the English court when it was illegal for Jews to live in England? Simply put, they were among the best string players in the world. How did they survive and even flourish under these conditions? It seems that their Jewishness apparently was not an issue. Great events in history usually occur as a result of the confluence of circumstances, and for the Lupos the timing of events could not have been more fortuitous. Without the horrendous events in Spain John Baptist might not have moved his family to musically rich Northern Italy and the Lupo brothers might not have grown up near the birthplace of the violin? What were the chances that Henry's older brother would die and that Henry, with his musical talent and excellent education, would become King of England? What if Henry had not separated the English Church from Rome and had not subsequently recruited Jews at that particular moment in history? ${ }^{108}$ When Henry had the Lupo brothers thrown into prison after their first year at court, who could have imagined that they would be quietly whisked out of the country and then reinstated in the string consort a year later?

108. Holman, Four and Twenty Fiddlers, 86-87. 
All these circumstances that occurred at precisely the right time could not have been anticipated under any condition. Yet they happened. Henry was king; he loved music; and, he quietly recruited Jews to England. He was pleased with the quality of the music at the court with the new musicians. And although the Lupos were expected to be members of the Christian Church, at least publicly, it was apparently a condition they were willing to accept in exchange for the freedom and quality of life they found in London. Regardless of the other circumstances, this likely would not have been possible were it not for Henry's live and let live attitude.

How likely was it that subsequent sovereigns would appreciate the music at the court and continue the service of the Jewish musicians? They survived the turbulent reigns of Protestant Edward VI and Catholic Bloody Mary without difficulty, and under the reign of Queen Elizabeth they experienced a long period of stability, due primarily to the strong relationship and bonds of trust that existed between Elizabeth and the Jewish musicians. ${ }^{109}$ Like Henry, Elizabeth had a live and let live philosophy. It even turned out that her physician, Dr. Rodrigo Lopez, was a Sephardic Jew from Spain. ${ }^{110}$

Is it then feasible to think that the Lupos might have played a role in changing the anti-Jewish laws? This would certainly be difficult to prove; on the other hand, the royal musicians enjoyed a unique relationship with the royal family and were especially favored compared to musicians outside the court. They earned considerably more money and were exempt from certain taxes and assessments. Several Jewish families, including the Lupo and Bassano families, became so assimilated in society that they immerged as part of the landed gentry. ${ }^{111}$ By amassing sufficient wealth and social status to garner the respect of London society, and through their close association with the royal families for over a century, surely it is feasible to think that they could have played a role in bringing about social change that eventually led to a change in the law.

The Resettlement Act of 1655 was unsuccessful, but when it failed to pass, Cromwell let it be known that he would not enforce the anti-Jewish laws anymore. This was an important step toward the passing of the Jewish Naturalization Act of $1753 .{ }^{112}$ And although it was repealed a year later, the social pressure continued to mount so that by the middle of the nineteenth century the Jewish Emancipation Act was finally passed, followed by the seating of Lionel de Rothschild in the British House of Commons on 26 July 1858, and

109. Ibid., 104.

110. The Jewish Encyclopedia, vol. 6, 181.

111. Ibid., 51.

112. Williams, Cassell's Chronology of World History, 316. 
the appointment a decade later of Benjamin Disraeli as Prime Minister. ${ }^{113}$ Considering their long journey and incredible accomplishments, the Lupo legacy certainly must be recognized as an integral part of bringing about the social change that eventually led to a change in the law.

The significance of the Lupo legacy in bringing about musical change is more apparent. First of all, their performance skills had to be outstanding enough to catch the attention of the agent who was assisting Cromwell in the first place, and then outstanding enough for the English string consort to become one of the leading ensembles in all of Europe. As first generation violinists they were pioneers in introducing the violin to England and in establishing it as the standard stringed instrument of the future. ${ }^{114}$ Lupo composers also played an integral role in the creation of the English Fantasia and its consequential influence on the development of new musical forms of the baroque period. Musicologist Manfred Bukofzer claims that the music of the English string consort in the seventeenth century, with its couples or single dances loosely strung together had a strong influence on the development of the orchestral suite of the later baroque period. ${ }^{115}$

The Lupo legacy is an amazing story of perseverance, survival and accomplishment. Coming from a most desperate situation on the Iberian Peninsula, they were offered a most unlikely opportunity in a most unexpected place. They were brave to accept the challenge, and in doing so they not only raised the standards of their art form but also helped to open the doors of society for others to follow. Truly, the Lupos must be remembered as agents for musical and social change.

\section{Bibliography}

A Biographical Dictionary of English Court Musicians, 1484-1741. Composed by Andrew Ashvee and David Lasacki, Assisted by Peter Holman and Fiona Kisby, vol. II. Aldershot: Ashgate, 1998.

Assis, Yom Tov. The News of Spain: From Settlement to Expulsion. Jerusalem: The Hebrew University of Jerusalem, 1988.

Bible, New International Version (NIV). Grand Rapids: Zondervan Press, 2011. Genesis 49: 27.

Baron, Salo Wittmayer. A Social and Religious History of the Jews: Christian Spain. New York: Columbia University Press, 1952.

113. Reader's Guide to British History, ed. David Loades, 2nd edition (New York: Fitzroy Dearborn, 2003), 1138-1139.

114. Holman, Four and Twenty Fiddlers, 87.

115. Bukofzer, Music in the Baroque Era, 72-75. 
Bukofzer, Manfred F. Music in the Baroque Era. New York: W. W. Norton \& Co., 1947.

Bangwere, Blanche. Music History During the Renaissance Period, 1520-1550. Westport, CT: Praeger Publishers, 2004.

Charteris, Richard. "A Rediscovered Source of English Consort Music." In Chelys 5 (1973-74).

Coldham, Peter Wilson. Complete List of Emigrants 1607-1660. Baltimore: Genealogical Publishing Co. Inc.

Dozy, Reinhardt. Spanish Islam: A History of the Muslims in Spain. Translated by Francis G. Stokes. London: Chatto \& Windus, 1913.

Documents of the English Reformation, edited by Gerald Bray. Cambridge: James Clarke \& Co., 2004.

Dart, Thruston. "Viols." In Musical Instruments through the Ages, edited by A. Baines. Baltimore: Penguin Books, 1961.

Documentos acerca de la expulsion de los Judios (Documents about the expulsion of Jews), No. 177, edited by Luis Suarez-Fernandez. Valladolid: C.S.I.C., 1964.

Field, Christopher D. S., et al., "Fantasia." In Grove Music Online, Oxford Music Online, Oxford University Press.

Gregorovius, Ferdinand. History of the City of Rome in the Middle Ages. Translated by Annie Hamilton, vol. VIII part 2. London: George Bell \& Sons, 1906.

Grantees of Arms Named in Docquets and Patents to the End of the Seventeenth Century, edited by Harry Rylands. London: Harleian Society Publications, 1915.

Gedaliah ibn Yahya ben Joseph. Shalshelet Ha-Kabbalah. Venice, 1587; reprinted Brookfield, MI: Targum Press, 2004.

Graetz, Heinrich. History of the Jews, vol. III. Philadelphia: The Jewish Publication Society of America, 1894.

Holman, Peter. "Thomas Lupo" under "Lupo family." In Grove Music Online. Oxford University Press.

Hillgarth, J. N. The Spanish Kingdoms: 1250-1516. Volume II: 1410-1516, Castilian Hegemony. Oxford: Clarendon/Oxford University Press, 1978.

Hunt, Lynn, Hsia, R. Pochia, Martin, Thomas R., Rosenwein, Barbara H., \& Smith, Bonnie. The Making of the West: Peoples and Cultures: A Concise History, Vol. I: To 1740, 2nd edition. New York: Bedford/St. Martin's, 2007.

Hillebrand, Harold N. "The Early History of the Chapel Royal." In Modern Philology 18, no. 5 (1920).

Holman, Peter. Four and Twenty Fiddlers: The Violin at the English Court 15401690. Oxford: University Press, 1993; reprinted by Clarendon Press, 1995.

Julius, Anthony. Trials of the Diaspora: A History of Anti-Semitism in England. Oxford: Oxford University Press, 2010.

Kamen, Henry. The Spanish Inquisition. New Haven: Yale University Press, 1999.

Kristeller, Paul Oskar. Renaissance Thought II: Papers on Humanism and the Arts. New York: Harper Torchbooks, 1965. 
Krinsky, Carol Herselle. Synagogues of Europe: Architecture, History, Meaning. Cambridge: MIT Press, 1985.

Katz, Solomon. "Monographs of the Mediaeval Academy of America." In No. 12, The Jews in the Visigothic and Frankish Kingdoms of Spain and Gaul. Cambridge: The Mediaeval Society of America, 1937.

Laeuchli, Samuel. Power and Sexuality: The Emergence of Canon Law at the Synod of Elvira. Philadelphia: Temple University Press, 1972.

Letters and Papers, Foreign and Domestic, of the Reign of Henry VIII, Vol. XVI. Arranged and cataloged by James Gairdner and R. H. Brodie. London: Eyre \& Spottiswoode, 1898 .

Lupo, Thomas. The Five-Part Consort Music, vol. 1, edited by Richard Charteris. London: Fretworks Editions, 1997.

Lea, Henry Charles. "Ferrand Martinez and the Massacres of 1391." In The American Historical Review 1, no. 2 (1896).

Moses ben Machir. Seder Ha-Yom. Venice: Gara, 1604.

Mundill, Robin R. England's Jewish Solution: Experiment and Expulsion. Cambridge: Cambridge University Press, 2004.

Mathew, Arnold H. The Life and Times of Rodrigo Borgia. London: S. Paul \& Co., 1912.

Nugent, Nell Marion. Cavaliers and Pioneers, vol. 1. Richmond: The Library of Virginia, 1992.

Prior, Roger. "Jewish Musicians at the Tudor Court." Musical Quarterly 69 (1983), 257-258.

Peters, Edward. Inquisition. New York: Free Press, 1988.

Prestwich, Michael. Edward I. New Haven: Yale University Press, 1997.

Prescott, William H. History of the Reign of Ferdinand and Isabella. New York: A. L. Burt, 1838 .

Rajman, H. U. A Chronology of Islanic History 570-1000, 3rd edition. London: Ta-Ha Publishers, Ltd, 1999.

Remnant, Mary. Musical Instruments of the West. London: Batsford, 1978.

Ring, Trudy, Salkin, Robert M., \& La Boda, Sharon. International Dictionary of Historic Places: Southern Europe. Chicago: Fitzroy Dearborn Publishers, 1994-96.

Reese, Gustave. Music in the Renaissance, 2nd edition. New York: W. W. Norton \& Co., Inc., 1959.

Reader's Guide to British History, edited by David Loades, 2nd edition. New York: Fitzroy Dearborn, 2003.

Saraiva, António José. "Introduction to the English edition." In The Marrano Factory: The Portuguese Inquisition and its New Christians. Translated by H. P. Solomon. Leiden: Brill Publishers, 2001.

Sarna, Nahum M. "Hebrew and Bible Studies in Medieval Spain." In Sephardi Heritage, vol. 1, edited by R. D. Barnett. New York: Ktav Publishing House, Inc., 1971. 
Stillman, Norman. "Aspects of Jewish Life in Islamic Spain." In Aspects of Jewish Culture in the Middle Ages, edited by Paul E. Szarmach. Albany: State University of New York Press, 1979.

Sholod, Barton. Charlemagne in Spain: The Cultural Legacy of Roncesvalles. Geneva: Droz, 1966.

Scruton, Roger. A Dictionary of Political Thought. New York: Macmillan Publishers, 1996.

Tolan, John. Europe and the Islamic World: A History. Princeton: Princeton University Press, 2013.

The Jewish Encyclopedia, edited by Isidore Singer, vol. 11. New York: Funk and Wagnalls, 1901.

Williams, Hywel. Cassell's Chronology of World History. London: Weidenfeld \& Nicolson, 2005.

Winternitz, Emmanuel. "Early Violins in Paintings by Gaudenzio Ferrari and his School." In Musical Instruments and Their Symbolism in Western Art. London: W. W. Norton \& Co., 1967.

Weir, Alison. Henry VIII. New York: Random House, Inc./Ballantine Books, 2008. 